\title{
Development of a Routes Guide Innovation for Historical, Cultural and Natural Resources U-thong District, Suphanburi Province
}

\author{
Wittaya Wisutruangdat ${ }^{\mathrm{a}}$ \\ ${ }^{a}$ Faculty of Humanities and Social Science, Bansomdejchaopraya Rajabhat University, wit_wittaya@ @otmail.com
}

Article History: Received: 10 November 2020; Revised 12 January 2021 Accepted: 27 January 2021; Published online: 5 April 2021

\begin{abstract}
The purpose of this research has develo a routes guide innovation for historical, cultural and natural resources Uthong district, Suphanburi Province. This research used quantitative research, and the research tools were questionnaires. Quantitative research had 2 steps. 1) Checked the validity of innovation a routes guide for historical, cultural and natural resources U-thong district, Suphanburi Province by the expects 9 key informants. Data were selected by using purposive sampling. 2) Checked complacency of innovation a routes guide by tourists visited tourist attractions 385 peoples. Used data selection method by multistage random sampling. Data was analyzed by mean and standard deviation. Results indicated that 1) the experts have had the appropriateness of content has been most appropriate at the highest level especially contents in the book have been easy to understand with the most suitable level. The appropriateness of photo arrangement appropriateness has been the least because some picture has been blurry. 2) The overall for complacency of innovation a routes guide was high level $\left(\mathrm{x}^{-}=4.29\right.$, S.D. $\left.=0.53\right)$. The highest complacency was benefits and values was at high level $\left(\mathrm{x}^{-}=4.41\right.$, S.D. $\left.=0.47\right)$. The lowest complacency was Language and it was at high level $\quad\left(x^{-}=4.23\right.$, S.D. $\left.=0.59\right)$. Suggestion of this study were 1$)$ there should be other innovations, and to strengthen tourism in U-thong district, and 2) should have travel routes for the elderly to come to travel in U-thong district.
\end{abstract}

Keywords: Routes Guide, U-thong District, Suphanburi Province.

\section{Introduction}

U-thong District has many tourist attractions. Suphanburi Provincehad a lot of benefits from tourist such as incomes, infrastructure, modernity etc. Consistent with [1] saidthe importance of tourism has affected the country: 1) Social 2) Economy and 3)Related people

From data [2]found that there were tourists who visited suphanburi in 2015 there were 900,490 people, in 2016 there were 945,223 people, an increase of $4.97 \%$. As a result, the average expenditure per tourist in 2016 was 1,470.78 baht per day, generating more than 1,390 million baht in tourism income. Therefore, if it can encourage tourists to visit suphanburi, it will generate a lot of income to the local people.

The Writing Routes Guide with various principles. So, [3] and [4] said manual writing principles can be summarized as follows: 1)Content 2) Language 3) Photo arrangement 4) Book arrangement and 5) Benefits and values

The travel route guide is importance to travel and the travel is importance to the income of the community and improving the quality of life of people within the community. For this reason, the researcher is interested in development of a routes guide innovation for historical, cultural and natural resources U-thong District, Suphanburi Province.To be a part of generating income and promoting the quality of life of people in the community for the better

\section{Research Objectives}

The objective of this research article was developed a routes guide innovation for historical, cultural and natural resources U-thong district, Suphanburi Province

\section{Literature Review}

In this research, the researcher studied literature related to manual writing principles.To develop a routes guide innovation. Mainly in writing a manual

Some experts wrote the following principles:

[3] said the good manual has been: 1)accuracy ofthe content 2) completeness of content 3) the form of 
manual 4) sorting the difficulty of content 5) accuracy in language useand 6) benefit fromreading

[4] said the good manual has been: 1)Language used in the manual, should been in a language that has been easy to understand, not complicated, used formal languageand should not have many academic languages 2) should have pictures 3) continuity and harmony of content 4) book permanence: stapling, quality of paper, size of manual and 5)quality of the manual production and printing: size of the font, lay out, correctness of the language

[5] said the good manual has been: 1) the nature of the book consists of cover design, overview of manual, Quality of paper, font sizeand page layout.

2) pictureconsists ofsharp, realism, size, number of pictures,annotations. 3) content consists of method of presentation, sorting difficulty, harmonization of thepassage, accurate events, additional activities. 4) use of language consists of language accuracy, Clarity of the message, accuracy of use of vocabulary and 5$)$ the reader's initiative after reading the manual.

[6] said the good manual has been: 1) content: accuracy, completeness, homogeneity, appropriate to the reader 2) the use of language: been easy to understand, has used the word that people has known, right in the meaning, carefully with spelling, use less academic vocabulary3)formatof manual: size of manual, cover paper, cover design, paper used for printing, stapling 4) printing: font size and style, print sorting,punctuation,Paragraph, spell, margin spacingand details about printing and $\quad$ 5) printing: components, foreword, contents, footnotes, bibliography, pictures, table.

According to the studied, it has found that writing a manual consisted of 1) content: accuracy, completeness,continuity, sorting difficulty, homogeneity, modernityand appropriate to the reader 2) the use of language: easy to understand, write fun, spell the word, writing was not complicated academic language use and clarity of the message 3) photo arrangement: sharp image, suitable size, cover photos can spark interest and beautiful, pictures could generate interest,picture color, picture matches the contentand composition of the picture 4) book arrangement:Suitability for use,thickness of manual, stapling, paper used for printing, font size and styleclarity of the text and easy to use 5) benefits and values: clarity of the history of attractions, generate interest of tourists, has helped plan travel routes for tourists, made to know the landmark of attractions, made to know connect routes of travel of attractions, and made knowledge of the tourist attractions

\section{Research Methods}

\section{A. Research Design}

This research has 2 steps:

1) Checked the validity of innovation a routes guide for historical, cultural and natural resources U-thong district, Suphanburi Province by the expects 9 key informants:

1) Assoc.Prof. Dr.Chollada Pongpattanayothin

Dean, Factory Humanities and Social Sciences / Lecturer in Library and Information Science Bansomdejchaopraya Rajabhat University

2) Asst.Prof. Sapiya Noomee

Head, Program in Library and Information Science Bansomdejchaopraya Rajabhat University

3) Asst.Prof. Praphaphan Hirunwatcharapruck

Lecturer in Library and Information Science Bansomdejchaopraya Rajabhat University

4)Asst.Prof. Dr.Touchakron Suwanchara

Head, Program in Digital Technology for Education Bansomdejchaopraya Rajabhat University

5) Assoc.Prof. Dr.Saknarat Prakobpon

Lecturer in Digital Technology for Education Bansomdejchaopraya Rajabhat University

6) Asst.Prof. Dr.Ruaysup Deshchaisri

Lecturer in Digital Technology for Education Bansomdejchaopraya Rajabhat University

7) Asst.Prof. Dr.Chiranuch Sopha

Lecturer inIndustry of Tourism Suan Dusit University

8) Asst.Prof. Dr.Napaporn Janchay 


\section{Lecturer in Industry of Tourism Suan Dusit University}

9) Dr.Rungnapa Lertpatcharapong

Lecturer in Industry of Tourism Suan Dusit University

Data were selected by using purposive sampling. 2) Checkedcomplacency of innovation a routes guide by tourists visited tourist attractions 385 peoples. Used data selection method by multistage random sampling. Data was analyzed by mean and standard deviation. The process of implementation consisted of

1)Documentary study from theory and related research of creating a travel route guide and the importance of tourist attractionsin U-thong district, Suphanburi Province

2) an area study of the importanceof tourist attractions in U-thong district, Suphanburi Province 3) Create a route guide innovation for Historical, Cultural and Natural Resources U-thong District, Suphanburi Province

4) soldto expert checked validity of innovation a routes guide

5) Updated on the advice of experts

6) Checked complacency of innovation a routes guide by tourists visited tourist attractions

7) Research finding

\section{B. Research Process}

Research process of this research had 7 steps consisted of to analyze concept, studied in the areas, created innovation route guide, Checked the validity of innovation a routes guide by the expect, approve by the expect, Checked complacency of innovation a routes guide by tourists and Research finding. Steps were shown in Fig. 1.

\begin{tabular}{|c|c|c|}
\hline Research Process & & Research Method \\
\hline Step 1 & & \\
\hline $\begin{array}{l}\text { Analyzed concept, theory and } \\
\text { related research about creating } \\
\text { a travel route guide and the } \\
\text { imbortance of tourist }\end{array}$ & $\longrightarrow$ & $\begin{array}{l}\text { - Studied documents and related } \\
\text { research. } \\
\text { - Studied of importance of tourist } \\
\text { attractions. }\end{array}$ \\
\hline $\begin{array}{c}\text { Step } 2 \\
\text { Studied in the areas }\end{array}$ & $\longrightarrow$ & $\begin{array}{l}\text { - Synthesized of data after studied } \\
\text { documents and related research. } \\
\text { - Studied data in the areas by in-depth } \\
\text { interview from local experts, local } \\
\text { philosopher and local leaders. }\end{array}$ \\
\hline $\begin{array}{c}\text { Step } 3 \\
\text { Created innovation route } \\
\text { guide }\end{array}$ & $\longrightarrow$ & $\begin{array}{l}\text { - Synthesized from primary data and } \\
\text { Secondary data. } \\
\text { - Created innovation route guide from } \\
\text { data found. }\end{array}$ \\
\hline $\begin{array}{c}\text { Step } 4 \\
\text { Checked the validity by the } \\
\text { expect }\end{array}$ & & $\begin{array}{l}\text { - The expects were from } 3 \text { disciplines: } \\
\text { Department of tourism industry, } \\
\text { Department of educational technology } \\
\text { and Department of library and }\end{array}$ \\
\hline $\begin{array}{c}\text { Step } 5 \\
\text { Approved by the expects }\end{array}$ & $\longrightarrow$ & - Updated on the advice of experts \\
\hline $\begin{array}{c}\text { Step } 6 \\
\text { Checked complacency by } \\
\text { tourists }\end{array}$ & $\longrightarrow$ & $\begin{array}{l}\text { - Tourists were who visited tourist } \\
\text { attractions } 385 \text { peoples. Used data } \\
\text { selection method by multistage } \\
\text { random sampling. }\end{array}$ \\
\hline $\begin{array}{c}\text { Step } 7 \\
\text { Research finding }\end{array}$ & $\longrightarrow$ & $\begin{array}{l}\text { - The data were form expects. } \\
\text { - The data were form tourists. }\end{array}$ \\
\hline
\end{tabular}

Fig.1 Research process for thedevelopment of a routes guide innovation for historical, cultural and natural Resources U-thong District, Suphanburi Province

\section{Score Setting Criteria}

This research used criteria of [7] has been 


\begin{tabular}{|c|c|}
\hline $\begin{array}{l}\text { Average } \\
\text { Score }\end{array}$ & Level of validity/complacency \\
\hline $4.51-5.00$ & highest \\
\hline $3.51-4.50$ & high \\
\hline $2.51-3.50$ & medium \\
\hline $1.51-2.50$ & low \\
\hline $1.00-1.50$ & lowest \\
\hline
\end{tabular}

\section{Results}

Results indicated that

1) Created routes guide can be divided into 3 groups. Each group consists of a navigator map, pictures of landmarks of tourist attractions, important of tourist attractions, QR code showed history of attractions, Opening and closing time, etc. Example of innovation details were shown in Fig. 2-5

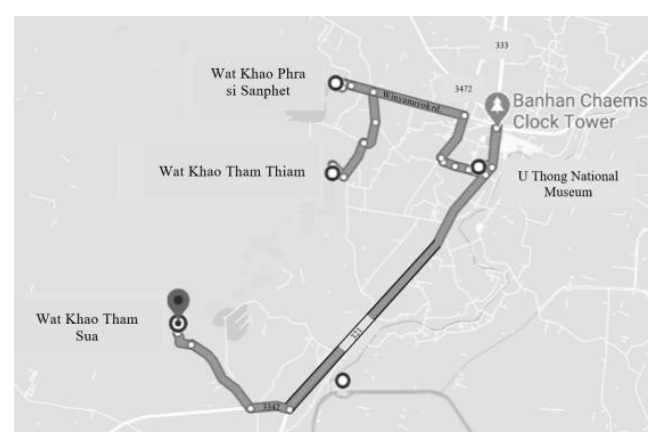

Fig.2 Examples of historical tourist routesmap

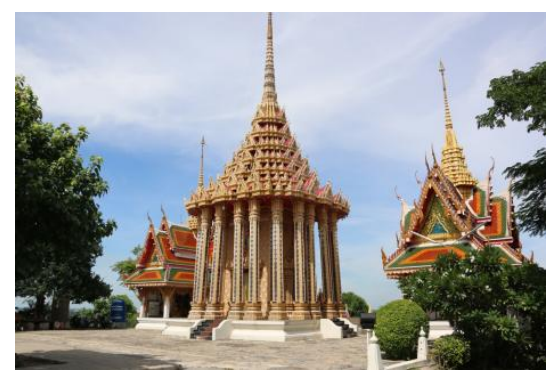

Pig.3 Landmarks of Wat khao phra si sanphetchayaram 


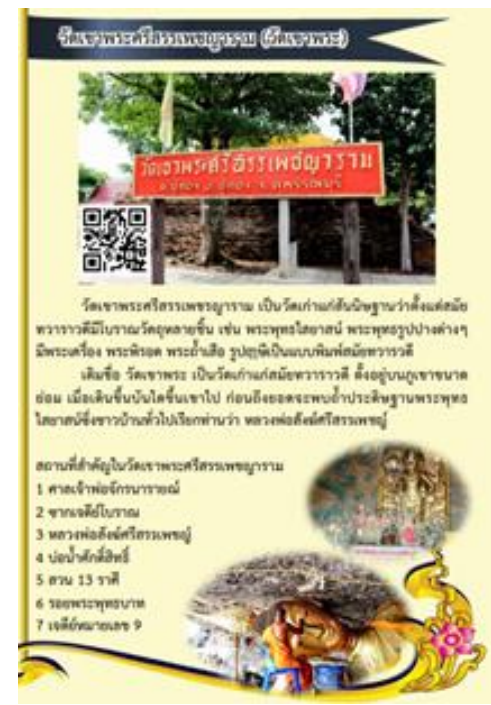

Fig.4 Example of information in the innovation

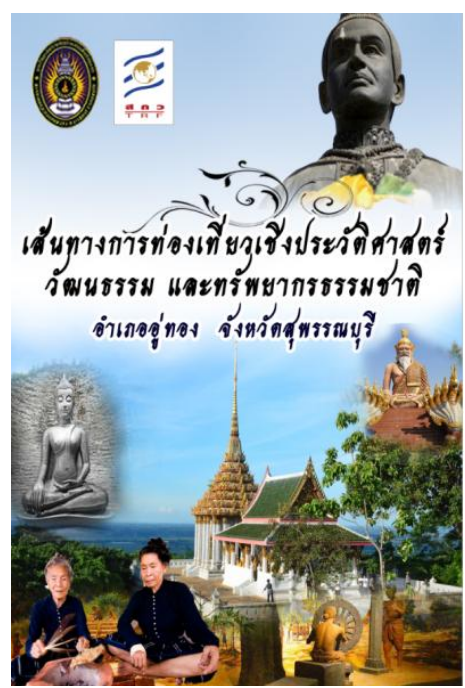

Fig.5 Cover of innovation

2) The research found appropriateness of routes guide innovation by the expects. has shown in table 1 .

Table 1. Appropriateness of routes guide innovation by the expects

\begin{tabular}{|l|c|c|c|}
\hline \multicolumn{1}{|c|}{ Appropriateness of routes guide } & $\overline{\mathbf{X}}$ & S.D. & Level \\
\hline 1 Content & 4.62 & .429 & The highest \\
\hline 2 The use of language & 4.54 & .325 & The highest \\
\hline 3 Photo arrangement & 4.44 & .503 & The high \\
\hline 4 Book arrangement & 4.47 & .329 & The high \\
\hline 5 Benefits and values & 4.56 & .251 & The highest \\
\hline \multicolumn{1}{|c|}{ Average } & 4.53 & .318 & The highest \\
\hline
\end{tabular}

3) Checked complacency of routes guide innovation by tourists. has shown in table 2.

Table 2.Complacency of routes guide innovation by tourists

\begin{tabular}{|l|c|c|c|}
\hline \multicolumn{1}{|c|}{ Complacency of routes guide } & $\overline{\mathbf{X}}$ & S.D. & Level \\
\hline 1 Content & 4.27 & .48 & The high \\
\hline 2 The use of language & 4.23 & .59 & The high \\
\hline 3 Photo arrangement & 4.27 & .59 & The high \\
\hline 4 Book arrangement & 4.26 & .50 & The high \\
\hline 5 Benefits and values & 4.41 & .47 & The high \\
\hline \multicolumn{1}{|c|}{ Average } & 4.29 & .53 & The high \\
\hline
\end{tabular}




\section{Discussions}

The experts have had overall appropriateness has been at the highest level. It has divided into categories; the appropriateness of content was the highest, the average of 4.62 was the highest level because the content is easy to understand, easy to use and practical to use. Consistent with the research of [3] found a good book should contain content that is accurate, up to date, accepted in the field, difficult - easy to fit the reader. Content appropriate for the age and experience of the reader. The content includes author's initiatives and experiences that benefit the academics. The appropriateness of photo arrangementappropriateness has been the least level, the average of 4.44 was the high level because some picture was blurry correspond to [6] found the pictures in thebook have been very important. It has been something that stimulates the reader's interest. Therefore, the pictures in the book has needed to convey meaning, relation with subject, sharp, etc.

The tourists have had overall complacency has been at the high level. It has divided into categories; benefit and values has been the highest, the average of 4.41 was the high level becauseinformation in the innovation has been usable. It has been the resulting information from collecting both primary and secondary information.Helping tourists to has got information from this innovationcorrespond to [3] has told the quality book meant a book that has been useful, important, reliable in the information and can be referenced. The use of language has been lowest level, the average of 4.23 was the high level because some of the languages used has been academic words. It has made difficult to understand correspond to [6] has told the use of language when writing a book requires language that has been easy to understand, has used the word that people has known, right in the meaning, carefully with spelling, use less academic vocabulary.

\section{Recommendations}

\section{A. Recommendations for Practices}

1Should print more routes guide innovation because it can actually be usedand help tourists to more interested.

2 Within tourist attractions should have publicity boards.

\section{B. Recommendations for Further Research}

1 Other tourism innovations should be studied more.

2 Should study the route guide by using bicycle.

\section{Conclusion}

In conclusion, the findings from the analysisof

The expects and tourists have found a routes guide innovation has been consistent with theattractions, easy to understand,the information has been usable, has benefits and values but pictures should be improved to have more clarity, use of language should use words that are easy to understand and use less academic vocabulary.

\section{References}

U. Choykeewong and Other, "Ecotourism", Bangkok: Sandaw, 2015.

Tourism \& sports office Suphanburi province, "Economic statistics: Tourism", Retrieved on. 28th July 2020, from http://.suphan.nso.go.th/ images/attachments/article/143/tourist.pdf.

Siam Technology College, "Criteria and methods for assessing the quality of textbooks or books to certify the quality of academic work", Retrieved on. 9th December 2017, from http://plan.siamtechno.ac.th/doc/a013.pdf.

S. Arsairach, "Analysis and evaluation of English textbooks", Master of Education Program in English Language Teaching, Department of Curriculum and Instruction Faculty of Education. Silpakorn University, 2007.

T.H. Yong, "Creation of literature and book", Bangkok: ACT, 2016

A. Wirasmith. "Creative book creation activities guide" Bangkok: Tharn aksorn publisher, 2014.

B. Srisaraard, "Population references when using estimation scale tools with sample groups", Journal of educational measurement Srinakharinwirot Mahasarakham University, vol.3, no.1, pp. 22 - 25, 1992. 